\title{
OBITUARY: HORACIO ARLÓ-COSTA
}

The present special issue is dedicated to the memory of Horacio Arló-Costa. The issue is based on the 20II Episteme Conference at Carnegie Mellon University, of which Arló-Costa was the main organizer. He would have been an editor of this issue, but under the circumstances, Christian List and Rohit Parikh have taken on the role of guest editors.

Horacio Arló-Costa, Professor of Philosophy at Carnegie Mellon University, passed away on I4 July 201 I, at the age of 54. Arló-Costa's academic mentors included formal epistemologists such as Carlos Alchourrón in Buenos Aires and Isaac Levi and Rohit Parikh in New York. After earning his PhD from Columbia University in I997, he joined the Philosophy Department at CMU, where he helped solidify its reputation in mathematical and scientific philosophy.

An enthusiastic and dedicated teacher, he taught a variety of subjects from philosophical logic and rational choice to philosophy of science and philosophy of mind, and contributed to Carnegie Mellon's Summer Program in Formal Epistemology. His most recent efforts in promoting formal epistemology were instrumental in creating its Center for Formal Epistemology, where he served as Associate Director.

A prolific and creative thinker, Arló-Costa made important contributions to several topics that are relevant to formal epistemology, from belief revision and epistemic conditionals to epistemic logic and sophisticated probabilism to normative and descriptive theories of decision making. His fifty-eight publications cover all these topics and more. He was also very active as an editor for the Journal of Philosophical Logic, Review of Symbolic Logic, and Synthese, as well as for several well respected volumes and special issues. Those who knew him will remember him not only as a highly imaginative and passionate philosopher but also as a kind and generous person. He will be much missed. 